\title{
PERBANDINGAN TINGKAT PRODUKSI DAN VOLUME PENJUALAN BAWANG DAUN ORGANIK DAN ANORGANIK DI KOPERASI MITRA SEJAHTERA CIANJUR
}

\author{
Oleh: \\ Nurjaya**) \\ Gunawan Ardiansyah*)
}

\begin{abstract}
Abstrak
Produk hortikultura merupakan komoditas perdagangan yang pengembangannya memegang peran strategis dalam menunjang peningkatan perekonomian daerah. Pengembangan usaha di bidang hortikultura merupakan salah satu upaya yang dilakukan pemerintah untuk meningkatkan kontribusi sektor pertanian. Bawang daun adalah salah satu jenis tanaman hortikultura yang berpotensi dikembangkan secara intensif dan komersil. Kabupaten Cianjur termasuk salah satu wilayah potensial untuk mengembangkan sayuran bawang daun. Bawang daun dapat tumbuh di daerah Cianjur dengan optimal karena struktur tanah mendukung, yaitu dengan tersedianya nutrisi atau unsur hara yang dibutuhkan tanaman. Tujuan penelitian ini untuk mengetahui perbedaan tingkat produksi bawang daun organik dan non organik dan untuk mengetahui perbedaan volume penjualan bawang daun organik dan non organik di Koperasi Mitra Sejahtera Cianjur. Penelitian ini dilaksanakan di Koperasi Mitra Sejahtera Cianjur Jl Gadog II Kecamatan Pacet Kabupaten Cianjur sejak bulan juli sampai dengan bulan agustus 2019. Dasar pemilihan lokasi ini dilakukan secara sengaja (purposive). Berdasarkan hasil penelitian ini bahwa tingkat produksi bawang daun organik sebesar $335 \mathrm{~kg}$ dan bawang daun anorganik $360 \mathrm{~kg}$ dengan luas lahan sama yaitu $7500 \mathrm{M}^{2}$. Dan volume penjualan bawang daun organik sebesar Rp. 2.847.500 dengan nilai jual Rp. 8.500/kg sedangkan bawang daun anorganik sebesar Rp. 2.700.000 dengan nilai jual Rp. $7.500 / \mathrm{kg}$.
\end{abstract}

Kata Kunci : Tingkat Produksi, Volume Penjualan, Bawang Daun Organik dan Bawang Daun Anorganik.

\begin{abstract}
Horticultural products are trade commodities whose development plays a strategic role in supporting the improvement of the regional economy. Business development in the field of horticulture is one of the efforts made by the government to increase the contribution of the agricultural sector. Leek is one type of horticulture plant that has the potential to be developed intensively and commercially. Cianjur Regency is one of the potential areas for developing leek vegetables. Onion can grow optimally in the Cianjur area because the soil structure supports, namely the availability of nutrients or nutrients needed by plants. The purpose of this study was to determine differences in the level of organic and non-organic onion production and to determine the differences in sales volume of organic and non-organic onions in Koperasi Mitra Sejabtera Cianjur. This research was conducted at the Cianjur Mitra Sejabtera Cooperative Jl Gadog II, Pacet Subdistrict, Cianjur Regency from July to August 2019. The basis for selecting the location was done intentionally (purposive). Based on the results of this study that the level of organic leek production is $335 \mathrm{~kg}$ and inorganic leek 360 $\mathrm{kg}$ with the same area of 7500 M2. And organic leek, sales volume of R. 2,847,500 with a selling value of R. 8,500 / kg while inorganic leeks are Rp. 2,700,000 with a selling value of Rp. 7,500 / kg.
\end{abstract}

Keywords :: Production level, Sales Volume, Organic Leeks and Inorganic Leeks.

*) Alumni Fakultas Sains Terapan UNSUR

**) Dosen Fakultas Sains Terapan UNSUR 


\section{PENDAHULUAN}

Komoditas perdagangan dalam pengembangan yang memegang peranan strategis untuk menunjang peningkatan perekonomian daerah yaitu salah satunya produk hortikultura. Yang dimana peningkatan perekonomian ini untuk meningkatkan kesejahteraan dan kemakmuran rakyat daerah serta penguatan ekonomi tingkat nasional. Selain daripada itu, pengembangan hortikultura tersebut mempunyai fungsi ekologi dan sosial. Secara ekologi merupakan membantu dalam melestarikan kualitas kehidupan alam. Sedangkan secara sosial merupakan untuk meningkatkan pemahaman masyarakat mengenai pemanfaatan hortikultura, memelihara kearifan lokal dan meningkatakan interaksi masyrakat.

Dalam pengembangan di bidang usaha hortikultura tersebut sebagai salah satu upaya untuk mengikatkan kontribusi pada sektor pertanian. Hal ini karena, hortikultura sebagai sumber pertumbuhan yang sangat berpotensial dan belum maksimal dimanfaatkan. Salah satu komoditas hortikultura seperti sayuran mempunyai nilai komersil sangat tinggi karena produk pertanian yang sering dikonsumsi setiap saat atau setiap hari. Oleh karena itu kebutuhan pasar terhadap sayuran selalu mengalami peningkatan secara terus meneru sehingga dengan adanya kecenderungan masyarakat yang digunakan untuk menerapkan pola hidup sehat dengan mengurangi konsumsi makanan berlemak tinggi dari bahan hewani ke bahan nabati.

Jenis tanaman hortikultura yang dimaksud yaitu bawang daun yang berpotensi untuk dikembangkan baik secara intensif maupun komersil. Pemasaran pada produk bawang daun segar ini tidak hanya dijual di pasar dalam negeri tetapi mencakup sampai luar negeri. Salah satu jenis bawang daun yang selalu diekspor ke luar negeri (Sinagpura dan Belanda) yaitu bawang daun varietas prei. Permintaan bawang daun ini akan semakin meningkat yang beriring dengan meningkatnya laju pertumbuhan penduduk. Permintaan tersebut, terutama untuk para perusahaa mie instant yang digunakan untuk bumbu bahan penyedap rasa (Sutrisna et al., 2013).

Berdasarkan data dari BPS tahun 2017 bahwa Kabupaten Cianjur termasuk salah satu daerah penghasil bawang daun yang cukup potensial di Jawa barat dengan rincian dapat di lihat pada tabel 1. 
Tabel 1. Produksi tanaman sayuran bawang daun di provinsi jawa barat tahun 2016.

\begin{tabular}{|c|c|}
\hline Kabupaten/Kota & Bawang Daun (Kwintal) \\
\hline Kabupaten & \\
\hline 1. Bogor & 21.548 \\
\hline 2. Sukabumi & 33.582 \\
\hline 3. Cianjur & 265.262 \\
\hline 4. Bandung & 599.401 \\
\hline 5. Garut & 499.324 \\
\hline 6. Tasikmalaya & 15.577 \\
\hline 7. Ciamis & 18.451 \\
\hline 8. Kuningan & 89.875 \\
\hline 9. Cirebon & - \\
\hline 10. Majalengka & 95.766 \\
\hline 11. Sumedang & 16.973 \\
\hline 12. Indramayu & - \\
\hline 13. Subang & 5.425 \\
\hline 14. Purwakarta & 9.401 \\
\hline 15. Karawang & - \\
\hline 16. Bekasi & - \\
\hline 17. Bandung Barat & 18.848 \\
\hline 18. Pangandaran & - \\
\hline Kota & \\
\hline 1. Bogor & 180 \\
\hline 2. Sukabumi & - \\
\hline 3. Bandung & 216 \\
\hline 4. Cirebon & - \\
\hline 5. Bekasi & - \\
\hline 6. Depok & - \\
\hline 7. Cimahi & 1.410 \\
\hline 8. Tasikmalaya & - \\
\hline 9. Banjar & 200 \\
\hline Jawa Barat & 1.691 .439 \\
\hline
\end{tabular}

Sumber Data : Badan Pusat Statistik, 2017.

Berdasarkan Tabel 1. tersebut Kabupaten Cianjur termasuk salah satu wilayah potensial untuk mengembangkan sayuran bawang daun. Bawang daun dapat tumbuh di daerah Cianjur dengan optimal karena struktur tanah mendukung, yaitu dengan tersedianya nutrisi atau unsur hara yang dibutuhkan tanaman. Pengaruh erosi, penguapan dan eksploitasi tanah secara sengaja mengakibatkan berkurangnya unsur hara di dalam tanah yang dibutuhkan oleh bawang daun (Cahyono, 2009). Selain itu, Bawang daun banyak mengandung saponin, tanin, dan minyak atsiri. Dengan kandungannya tersebut bawang daun berkhasiat untuk meredakan perut kembung, batuk, flu, sesak nafas karena flu, diuretick, diaforetik, nyeri sendi dan anti radang, menghilangkan bengkak karena bisul serta menghilangkan bekas gigitan serangga (Rukmana. 2008).

Koperasi Mitra Sejahtera Cianjur merupakan salah satu tempat untuk membudidayakan dan memasarkan produk hortikultura seperti kol, paprika, casin, timun, tomat, bawang daun dan beberapa sayuran organik. Koperasi Mitra Sejahtera Cianjur memiliki beberapa anggota dalam membantu pengelolaan produksi dan pemasarannya dimana masing-masing anggota mempunyai tugas 
masing-masing diantarnya yaitu bekerja sebagai pembudidaya lahan, pencucian, pembersihan, pengepakan dan pengiriman ke pasar, super market dan mini market.

Permasalahan pada tingkat produksi dan volume penjualan dalam Koperasi Mitra Sejahtera Cianjur merupakan salah satu bagian yang sangat penting. Pemasaran yang dilakukan dengan strategi yang baik akan menempatkan produk pada posisi yang tepat dan menguasai pasar. Proses produksi yang masih mendapatkan tantangan dari pihak eksternal berupa kepercayaan konsumen serta dituntut untuk mengatur dan mengelola suatu usaha dengan baik dan memperhatikan faktor produk, harga, distribusi, sehingga menarik untuk dikaji bagaimana penerapan proses produksi untuk meningkatkan volume penjualan pada usaha agribisnis tersebut.

\section{METODE PENELITIAN}

Penelitian ini dilaksanakan di Koperasi Mitra Sejahtera Cianjur J1 Gadog II Kecamatan Pacet Kabupaten Cianjur. Dasar pemilihan lokasi ini dilakukan secara sengaja (purposive), dengan pertimbangan bahwa Koperasi Mitra Sejahtera Cianjur merupakan salah satu sentra penghasil bawang daun di Kabupaten Cianjur dan Koperasi Mitra Sejahtera Cianjur merupakan salah satu tempat produksi dan pemasaran bawang daun. Adapun waktu pelaksanaan penelitian ini dimulai dari bulan Juli sampai dengan Agustus 2019. Variabel penelitian ini adalah perbandingan tingkat produksi dan volume penjualan bawang daun organik dan non organik. Secara rinci, operasional variable penelitian tercantum pada table 2 .

Tabel 2. Variabel penelitian.

\begin{tabular}{|c|c|c|c|}
\hline $\begin{array}{l}\text { Variabel } \\
\text { Penelitian }\end{array}$ & Konsep Variabel & Indikator & Skala \\
\hline Produksi & $\begin{array}{l}\text { Produksi sering didefenisikan sebagai } \\
\text { penciptaan guna, dimana guna } \\
\text { bararti kemampuan barang atau jasa } \\
\text { untuk memenuhi kebutuhan } \\
\text { manusia (Ari Sudarman, 2004). }\end{array}$ & $\begin{array}{l}\text { Kebutuhan Bibit Bawang Daun } \\
\text { Kebutuhan Pupuk } \\
\text { Penggunaan Pestisida } \\
\text { Modal } \\
\text { Luas lahan } \\
\text { Jumlah tenaga kerja } \\
\text { Jumlah produksi }\end{array}$ & Nominal \\
\hline $\begin{array}{l}\text { Volume } \\
\text { Penjualan }\end{array}$ & $\begin{array}{l}\text { Volume penjualan adalah barang yang } \\
\text { terjual dalam bentuk uang untuk jangka } \\
\text { waktu tertentu yang didalamnya } \\
\text { mempunyai strategi pelayanan yang } \\
\text { baik. (Kotler, 2000) }\end{array}$ & $\begin{array}{l}\text { Harga Produk } \\
\text { Jumlah produk yang terjual } \\
\text { Metode penjualan }\end{array}$ & Nominal \\
\hline
\end{tabular}

Penentuan sampel dilakukan dengan metode yang bersifat non probability sampling dengan teknik purposive sampling. Menurut Arikunto (2010), purposive sampling yaitu teknik yang digunakan oleh peneliti dengan pertimbanganpertimbangan tertentu didalam pengambilan sampelnya.

Responden dalam penelitian ini merupakan informan kunci yang dipilih karena dianggap lebih mengetahui permasalahan yang diteliti berdasarkan tugas dan tanggung jawabnya dalam perusahaan dan kaitannya dengan kegiatan produksi dan penjualan. Responden tersebut terdiri dari pimpinan koperasi, sekretaris, bagian produksi dan bagian penjualan bawang daun pada Koperasi Mitra Sejahtera Cianjur.

Analisis deskriptif adalah statistik yang digunakan untuk menganalisa data dengan cara menggambarkan atau mendeskripsikan data yang telah terkumpul sebagaimana adanya tanpa ada maksud membuat kesimpulan yang berlaku untuk umum atau generalisasi (Sugiyono, 2007). Statistik deskriptif dapat digunakan bila hanya ingin 
mendeskripisikan sample saja dan tidak ingin membuat kesimpulan yang berlaku untuk populasi dimana sample diambil. Sedangkan menurut Nazir (2005), analisis deskriptif adalah suatu metode dalam meneliti manusia, suatu objek, suatu kondisi, suatu sistem pemikiran ataupun suatu kelas peristiwa pada masa sekarang.

Analisis ini mempelajari masalahmasalah dalam masyarakat, serta tata cara yang berlaku dalam masyarakat serta situasi-situasi tertentu. Pada penelitian ini analisis deskriptif digunakan untuk membandingkan tingkat produksi dan volume penjualan bawang daun organik dan non organik di Koperasi Mitra Sejahtera Cianjur. Analisis deskriptif ini disajikan dalam bentuk uraian dan tabulasi sederhana.

Metode yang digunakan dalam penelitian ini adalah deskriftif kualitatif, penelitian ini ingin menggambarkan atau melukiskan objek penelitian berdasarkan fakta-fakta yang tampak atau sebagaimana adanya (Nawawi, 2012). Penelitian deskriftif kualitatif berusaha mendeskripsikan seluruh gejala atau keadaan yang ada, yaitu keadaan gejala menurut apadanya pada saat penelitian dilakukan (Mukhtar, 2013). Dalam hal ini ingin menggambarkan bagaimana tingkat produksi dan volume penjualan bawang organik dan bawang non organik di Koperasi Mitra Sejahtera.

\section{HASIL DAN PEMBAHASAN}

Koperasi Mitra Sejahtera Cianjur didirikan pada tahun 13 Oktober 2003, Oleh Nanang Rahman SE dari BMT AsSalam, Yetno Suprayetno dari Kharisma Boga, CV. Ladang Panajang dan Wartono Taufik Ismail dari CV. Anugrah Potensi Indonesia (APOI), di Jl. Gadog II No. 18 Kecamatan Pacet Kabupaten Cianjur. Kemudian disahkan berdasarkan surat keputusan Kementrian Koperasi dan Usaha Kecil Menengah (UMKM) nomor 1040/BH/XIII.7/Bid.KOP/2016

tangggal 10 Oktober 2005. Dengan tujuan untuk mewujudkan kesejahteraan petani melalui pembinaan dan proses produksi dan pemasaran yang terpadu yang nantinya berdampak pada optimalisasi produksi petanian serta menjadi salah satu langkah terwujudnya Kedaulatan Pangan Nasional, menjadi motivasi tersendiri dan landasan bagi pengelola Koperasi Mitra Sejahtera Cianjur dalam menjalankan usahanya.

Koperasi Mitra Sejahtera sudah mulai menerapkan tekhnologi produksi yang senantiasa sebagai kekuatan di sektor hulu dan penerapan pasca panen dengan melakukan standarisasi yang telah disesuaikan dengan permintaan pasar yang berorientasi ke produk unggulan berdaya saing. Untuk menjaga kestabilan harga, Koperasi Mitra Sejahtera membangun kemitraan pemasaran dari pasar tradisional hingga Pasar Modern (supermarket) dengan melakukan penanganan dari hulu hingga hilir, sehingga dapat menjawab permasalahan petani selama ini.

Koperasi Mitra Sejahtera sudah menjalani kemitraan dengan berbagai elemen baik dalam bidang produksi, pemasaran dan lembaga pemerintah. Adapun kemitraaan di bidang produksi menjalin kerjasama dalam mengadakan produk-produk pertanian yang dibutuhkan melalui pembinaan dengan Kelompok Tani dan Gabungan Kelompok Tani (Gapoktan) sebagai berikut: Gapoktan Karya Tani Cibeureum-Cugenang-Cianjur, Gapoktan Mujagi Pacet-Cianjur, Gapoktan Agropolitan Cipanas-Cianjur, Gapoktan Jambu Kristal Mandiri Bogor, Gapoktan Sauyunan Rangkasbitung-Banten, Kelompok Tani Kharisma Boga-Cianjur, dan Kelompok Tani Mina Sari Subur Sukabumi.

Kemitraan di bidang pemasaran dilakukan untuk menjalin kerjasama dalam memasarkan atau mensuplai hasil pertanian ke pasar-pasar modern sebagai berikut: Toserba Yogya (PT.Akur Pratama), Toserba Ada Bogor dan Toko Today Jakarta. Selain itu, Koperasi Mitra Sejahteran juga menjalin kerjasama atau bermitra dengan kelembagaan pertanian yang bertujuan untuk berkonsultasi 
mengenai permasalahan yang dihadapi Koperasi Mitra Sejahtera, diantaranya dengan Dinas Pertanian Tanaman Pangan dan Hortikultura., Dinas Koperasi UMKM, Dinas Perdagangan Perindustrian, Pusat Layanan Usaha Terpadu (PLUT), Koperasi Syariah Assalam Cianjur, Sub Terminal Agribisnis Cigombong-Cianjur dan Asosiasi Pasar Tani.

Responden yang diambil untuk diwawancarai berjumlah 4 orang yang terdiri dari : Ketua, Sekertaris, bagian produksi dan bagian pemasaran di Koperasi Mitra Sejahtera. Sebelumnya ke 4 responden tersebut telah memiliki banyak pengalaman bidang pertanian bahkan menjadi pimpinan diberbagai $\mathrm{CV}$.

Adapun ke 4 responden tersebut:

1. YETNO SUPRAYETNO (Ketua Pengurus)

Berpengalaman dalam dunia usaha agribisnis, beliau pernah menjadi pengurus diperusahaan Bob Sadino( Pengusaha sukses di Indonesia). Dan selain menjabat di Koperasi Mitra Sejahtera, beliau juga menjabat sebagai direktur di CV Kharisma Boga dan menjabat sebagai pengurus STA ( Sub Terminal Agribisnis).

2. WARTONO TAUFIK ISMAIL (Sekertaris)

Berpengalaman dalam bidang administrasi, sudah 4 tahun menjadi sekertaris di CV Anugerah Potensi Indonesia (APOI), bahkan pernah menjadi konsultan bidang Akses Pembiayaan, Pendamping P3UKM.

3. ABDAN (Produksi)

Berpengalaman dalam bidang budidaya sayuran, dan beliau juga sebagai Pengusaha Sukses budidaya Jamur.

4. ACHMAD PARIS RIDWAN, SEi (Pemasaran) Berpengalaman dalam mengelola usaha koperasi, beliau menjabat sebagai Manager di BMT EL-FAJR.

Bawang daun organik dan anorgaik yang ditanam oleh petani Koperasi Mitra Sejahtera yaitu jenis bawang daun prei. Bawang daun ini sudah umum ditanam di indonesia karena kondisi lahan dan cuaca yang sangat sesuai untuk pengembanganya. Selain itu, pembudidayaan bawang daun prei relatif mudah dan murah. Bawang daun organik dan anorganik di Koperasi Mitra Sejahtera dipanen setelah tanaman berumur 70 hari setelah tanam, dengan tanda beberapa bagian dari bagian bawah daun telah berwarna menguning atau mengering, jumlah anakan bawang daun berjumlah 710 anakan. Panen dilakukan dengan mencabut seluruh bagian tanaman atau rumpun. Perlakuan budidaya bawang daun anorganik berbeda dengan bawang daun organik, yang membedakanya dari pemberian pupuk dan pestisida yang menggunakan bahan kimia.

Bibit bawang daun organik maupun anorganik diperoleh dari petani binaan Koperasi Mitra Sejahtera yang menjadi penangkar bibit bawang daun, yang sebelumnya bibit tersebut berasal dari benih yang telah disemai selama 2 bulan dengan ketinggian $10-15 \mathrm{~cm}$ dengan rumpun 1-3 helai daun yang siap untuk ditanam di lahan produksi dan untuk perlakuan bibit tidak dibedakan. Kebutuhan bibit yang digunakan untuk luas lahan 1,5 hektar yaitu 200.000 batang bawang daun. Yang masing-masing 100.000 batang bawang daun untuk perlakuan organik dan 100.000 batang bawang daun untuk perlakuan bawang anorganik.

Pupuk yang digunakan dalam melakukan budidaya bawang daun organik dan anorganik berasal dari toko pertanian dengan membeli. Adapun Pemupukan untuk bawang daun organik dan anorganik dilakukan sebanyak 2 kali yaitu pada saat tanaman berumur 20 dan 42 hari setelah tanam (HST), yang membedakan yaitu jenis pupuk yang digunakan. Adapun jenis pupuk yang digunakan untuk bawang daun organik untuk luas lahan $7.500 \mathrm{~m}^{2}$ yaitu pemupukan susulan pertama menggunakan pupuk organik padat $5 \mathrm{~kg}$ dengan di buat larutan dengan air $1000 \mathrm{ml}$ serta untuk pemupukan kedua dengan dosis pupuk organik padat $2 \mathrm{~kg}$. Dan 
untuk pemupukan bawang daun anorganik menggunakan pupuk kimia dengan menggunakan pupuk NPK dengan kebutuhan $50 \mathrm{~kg}$ untuk satu kali musim, terbagi pada pemupukan susulan pertama dengan dosis $30 \mathrm{~kg}$ dan untuk pemupukan kedua $20 \mathrm{~kg}$.

OPT (organisme pengganggu tanaman) yang ditemukan di areal penanaman bawang daun anorganik antara lain ulat tanah (Agrotis ipsilon), hama ini bisa membuat tanaman rebah, pangkal batang yang diserang bisa membuat batang terpotong hingga putus. Pengendalian secara kimia dengan menggunakan insektisida Dursban 20 EC dengan dosis 2-3 $\mathrm{ml} /$ liter. Dan jenis penyakit yang menyerang Ervinia carotrovora, cirinya batang yang terserang busuk, basah, dan mengeluarkan bau tak enak. Pengendalian yang dilakukan dengan mengunakan baktersidia dengan bahan aktif klorotalonil.

Sumber modal yang digunakan Koperasi Mitra Sejahtera Cianjur dalam mengembangkan atau membudidayakan bawang daun organik dan anorganik berasal dari simpanan pokok dan simpanan wajib anggota atau modal sendiri yang dikelola oleh Koperasi Mitra Sejahtera. Adapun modal yang digunakan sejumlah Rp. 17.000.000/tahun (tujuh belas juta rupiah), dimana jumlah tersebut masih skala kecil karena belum cukup tinggi dalam pengembangan budidaya bawang organik dan anorganik. Modal tersebut digunakan untuk memenuhi kebutuhan produksi bawang daun organik dan anorganik dalam semusim yang terdiri dari pemenuhan bibit, pupuk, pestisida, dan tenaga kerja.

Luas lahan penggarapan secara keseluruhan untuk budidaya bawang daun organik dan anorganik yaitu seluas 1.5 hektar, masing-masing luas lahan yang digunakan untuk bawang daun organik dan anorganik yaitu $7.500 \mathrm{M}^{2}$. Lahan yang digunakan merupakan milik Koperasi Mitra Sejahtera, serta lokasi lahan tidak jauh dari Koperasi Mitra Sejahtera untuk lebih mudah dalam melakukan monitoring. Adapun kondisi lahan yang digunakan untuk melakukan budidaya bawang daun organik layak digunakan karena melihat dari sejarah lahan cukup baik kesuburannya serta sebelumnya lahan tidak digunakan untuk budidaya sayuran yang se famili dengan bawang daun. Dan jarak lahan budidaya bawang daun organik dan anorganik berkisar 1 KM (1000 meter), pemberian jarak tersebut untuk mencegah kontaminasi hama penyakit dan kontaminasi masing-masing perlakuan.

Tenaga kerja yang diperdayakan oleh Koperasi Mitra Sejahtera dalam pengembangan bawang daun organik dan anorganik berjumlah 7 orang terdiri dari 3 orang laki-laki dengan upah Rp. 55.000/HOK/6 hari kerja dan 4 orang perempuan dengan upah Rp. 45.000/HOK/6 hari kerja. Sistem kerja untuk 7 orang ini dibagi menjadi dua yaitu di lahan bawang daun organik dan lahan bawang daun anorganik sesuai dengan kondisi kebutuhan serta kondisi pekerjaan disetiap lahan. Dan untuk 7 tenaga kerja ini merupakan binaan dari Koperasi Mitra Sejahtera yang telah terikat kerja.

Sistem panen bawang daun organik dan anorganik yang dilakukan oleh Koperasi Mitra Sejahtera yaitu dengan sistem rotasi. Dimana sistem rotasi ini, panen dilakukan secara berputar atau tidak pada satu titik. Sehingga panen bawang daun hampir setiap hari dilakukan oleh Koperasi Mitra Sejahtera. Adapun data yang peneliti ambil dari Koperasi Mitra Sejahtera mengenai produksi bawang daun organik dan anorganik yaitu selama tiga bulan dari bulan mei sampai juli 2019 dengan luas lahan 1.5 hektar. Hal tersebut dilakukan karena sesuai dengan kebutuhan peneliti untuk membandingkan volume produksi dan volume penjualan bawang daun organik dan anorganik di Koperasi Mitra Sejahtera. Adapun data yang diambil sebagai berikut: 
Tabel 3. Jumlah produksi bawang daun di Koperasi Mitra Sejahtera.

\begin{tabular}{lcc}
\multirow{2}{*}{ Waktu Panen } & \multicolumn{2}{c}{ Jumlah Produksi (kg/0,75 Ha) } \\
\cline { 2 - 3 } Mei 2019 & Bawang Daun Organik & Bawang Daun Non Organik \\
\hline Panen ke-1 & 20 & 20 \\
Panen ke-2 & 30 & 30 \\
Panen ke-3 & 30 & 20 \\
Panen ke-4 & 20 & 20 \\
Jumlah & 100 & 90 \\
\hline Juni 2019 & & \\
\hline Panen ke-1 & 25 & 30 \\
Panen ke-2 & 20 & 20 \\
Panen ke-3 & 25 & 30 \\
Panen ke-4 & 40 & 27 \\
Jumlah & 110 & 107 \\
\hline Juli 2019 & & \\
\hline Panen ke-1 & 25 & 40 \\
Panen ke-2 & 25 & 20 \\
Panen ke-3 & 25 & 50 \\
Panen ke-4 & 50 & 53 \\
Jumlah & 125 & 163 \\
Total Produksi & 335 & 360 \\
\hline
\end{tabular}

Sumber : Data Primer, 2019.

Berdasarkan data diatas rata- rata selisih jumlah produksi bawang daun organik dan anorganik pada bulan meijuni yaitu $5-10 \mathrm{~kg}$. Dan untuk bulan juli mencapai peningkatan jumlah produksi dengan selisih pada akhir bulan juli mencapai 20-25 kg, hal ini dikarenakan serangan hama penyakit yang terjadi pada bawang daun anorganik dan organik pada bulan mei-juni lebih intens. Dan pada bulan juli dilakukan tindakan refresif atau penindakan setelah terkena hama penyakit dengan menggunakan pestisida dan pupuk kimia yang menyebabkan produksi bawang daun anorganik menjadi lebih tinggi serta untung bawang daun organik menggunakan pestisida nabati atau organik.

Berdasarkan data di atas menunjukan untuk produksi bawang daun anorganik tertinggi terjadi pada bulan juli dengan jumlah $163 \mathrm{~kg}$, hal tersebut dikarenakan serangan terhadap hama penyakit berkurang yang awalnya menyerang secara intens pada awal bulan mei sehingga produksi menurun atau paling terendah dengan jumlah $90 \mathrm{~kg}$. Serangan hama penyakit yang terjadi pada bawang daun anorganik lebih resisten sehingga perbedaan jumlah produksi lebih besar. Tindakan refresif atau penindakan setelah terkena hama penyakit dengan menggunakan pestisida dan pupuk kimia yang menyebabkan produksi bawang daun anorganik menjadi lebih tinggi.

Produksi bawang daun organik dan anorganik mengalami peningkatan produksi dari bulan Mei sampai Juli. Hal ini terlihat dari grafik 4.1 yang menunjukkan adanya peningkatan sebesar $25 \mathrm{~kg}$ untuk bawang daun organik dan 73 kg untuk bawang daun non organik (dari bulan Mei - Juli 2019). 


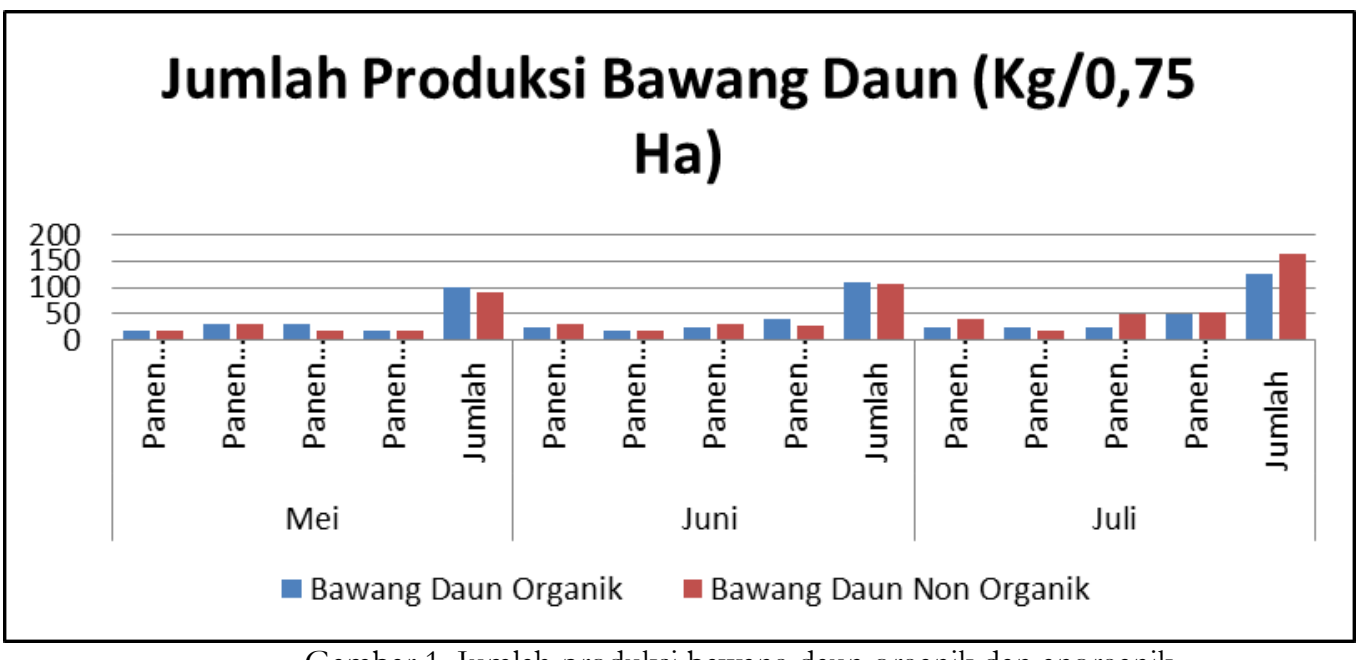

Gambar 1. Jumlah produksi bawang daun organik dan anorganik.

Dari grafik diatas mengenai produksi bawang daun organik, terjadi peningkatan produksi yang signifikan dari bulan mei sampai bulan juli. Peningkatan produksi pada bawang daun organik disebabkan berkurangnya serangan hama penyakit yang sangat mempengaruhi terhadap hasil yang diperoleh dan pemberian pestisida dan pupuk organik secara optimal terhadap tanaman, yang mampu meningkatkan produktivitas bawang daun organik.
Dari grafik diatas mengenai produksi bawang daun anorganik, terjadi peningkatan produksi yang signifikan dari bulan mei sampai bulan juli. Peningkatan produksi pada bawang daun anorganik disebabkan berkurangnya serangan hama penyakit yang sangat mempengaruhi terhadap hasil yang diperoleh dengan melakukan pemberian pestisisda dan pupuk kimia secara intens dan proposional sehingga produksi bawang daun anorganik menjadi lebih tinggi.

\section{Perbandingan Tingkat Produksi Bawang Daun Organik dan Anorganik}

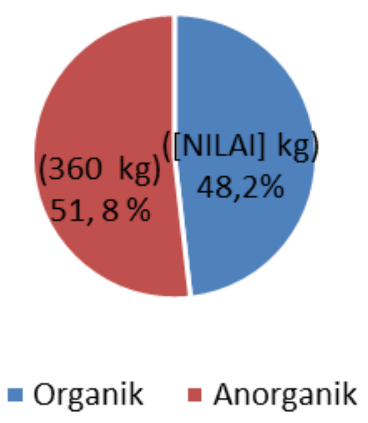

Gambar 2.Perbandingan produksi bawang daun organik dan anorganik.

Untuk jumlah produksi bawang daun organik dan anorganik selama rentan 3 bulan berbeda, terhitung untuk bawang daun organik total produksinya berjumlah $335 \mathrm{~kg}$ dan untuk bawang daun anorganik berjumlah $360 \mathrm{~kg}$. Produksi untuk bawang daun anorganik lebih besar daripada bawang daun organik, hal ini dikarenakan perlakuan budidaya anorganik berbeda dengan organik. Budidaya bawang daun 
anorganik memakai bahan kimia seperti pupuk dan pestisida sehingga pertumbuhan bawang daun anorganik lebih cepat dibandingkan bawang daun organik.

Penjualan bawang daun organik berkisar Rp.8.500/kg dan untuk bawang daun anorganik berkisar Rp.7.500/kg.
Bawang daun organik lebih mahal dari bawang daun anorganik dikarenakan permintaan bawang daun organik lebih tinggi daripada bawang daun anorganik serta bawang daun organik jumlah produksinya lebih sedikit. Adapun data penjualan selama 3 bulan dari Mei - Juli 2019 dapat dilihat pada Tabel 4.

Tabel 4. Data penjualan selama 3 bulan dari Mei - Juli 2019.

\begin{tabular}{|c|c|c|c|c|}
\hline \multirow{2}{*}{ Waktu Panen } & \multicolumn{2}{|c|}{$\begin{array}{c}\text { Bawang Daun Organik } \\
\text { (Rp. 8.500,-/kg) }\end{array}$} & \multicolumn{2}{|c|}{$\begin{array}{c}\text { Bawang Daun Non Organik } \\
\text { (Rp. 7.500,-/kg) }\end{array}$} \\
\hline & $\begin{array}{c}\text { Volume } \\
\text { Penjualan (kg) }\end{array}$ & $\begin{array}{l}\text { Total Penjualan } \\
\text { (volume } x \text { harga) }\end{array}$ & $\begin{array}{c}\text { Volume } \\
\text { Penjualan (kg) }\end{array}$ & $\begin{array}{l}\text { Total Penjualan } \\
\text { (volume } x \text { harga) }\end{array}$ \\
\hline \multicolumn{5}{|l|}{ Mei 2019} \\
\hline Panen ke-1 & 20 & 170.000 & 20 & 150.000 \\
\hline Panen ke-2 & 30 & 255.000 & 30 & 225.000 \\
\hline Panen ke-3 & 30 & 255.000 & 20 & 150.000 \\
\hline Panen ke-4 & 20 & 170.000 & 20 & 150.000 \\
\hline Jumlah & 100 & 850.000 & 90 & 675.000 \\
\hline \multicolumn{5}{|l|}{ Juni 2019} \\
\hline Panen ke-1 & 25 & 212.500 & 30 & 225.000 \\
\hline Panen ke-2 & 20 & 255.000 & 20 & 150.000 \\
\hline Panen ke-3 & 25 & 212.500 & 30 & 225.000 \\
\hline Panen ke-4 & 40 & 340.000 & 27 & 202.500 \\
\hline Jumlah & 110 & 935.000 & 107 & 802.500 \\
\hline \multicolumn{5}{|l|}{ Juli 2019} \\
\hline Panen ke-1 & 25 & 212.500 & 40 & 300.000 \\
\hline Panen ke-2 & 25 & 212.500 & 20 & 150.000 \\
\hline Panen ke-3 & 25 & 212.500 & 50 & 375.000 \\
\hline Panen ke-4 & 50 & 425.000 & 53 & 397.500 \\
\hline Jumlah & 125 & 1.062 .500 & 163 & 1.222 .500 \\
\hline $\begin{array}{c}\text { Total } \\
\text { Penjualan } \\
\text { Mei - Juli } \\
\text { (Rp.) }\end{array}$ & \multicolumn{2}{|c|}{2.847 .500} & \multicolumn{2}{|c|}{2.700 .000} \\
\hline
\end{tabular}

Sumber : Data Primer, 2019.

Berdasarkan data penjualan diatas menunjukan bahwa harga jual bawang daun organik dan non organik terpaut berbeda dengan nominal perbedaan yaitu Rp. 1000 ( seribu rupiah), hal tersebut dikarenakan permintaan bawang daun organik lebih tinggi, produksinya lebih rendah, lebih sehat dan bebas pestisida kimia, sehingga upaya pengendalian hama lebih intensif yang menyebabkan terjadinya perbedaan harga jual. Dan dari hasil total penjualan pun bawang daun organik lebih tinggi penjualanya dengan total Rp. 2.847.500 dibandingkan dengan bawang daun anorganik dengan total penjualan Rp.2.700.000, yang terpaut perbedaan dengan nominal Rp. 147.000 (seratus empat puluh tujuh ribu rupiah). Hal ini menunjukan bahwa dari segi penjualan bawang daun organik lebih menguntungkan dan tidak perlu ada biaya untuk pembelian pestisida dan pupuk kimia yang semakin hari semakin meningkat.

Metode penjualan yang dilakukan oleh Koperasi Mitra Sejahtera dalam memasarkan atau menjual bawang daun organik dan anorganik dengan melakukan kerjasama atau menjalin kontrak dengan supermarket-supermarket di wilayah Cianjur dan Jakarta. Untuk wilayah Cianjur, Koperasi Mitra Sejahtera bekerja sama dengan Yogya Cianjur dan untuk di wilayah Jakarta bekerja sama dengan 
Yogya dan Carefour. Koperasi Mitra Sejahtera mendistribusikan bawang daun organik dan bawang daun anorganik ke supermarket-supermarket di Cianjur dan Jakarta, setiap satu minggu sekali dengan kuantitas setiap pendistribusian yang ditentukaan oleh pihak supermarket sesuai kontrak yang telah disepakati sebelumnya.

\section{KESIMPULAN}

Dari hasil penelitian tentang perbandingan tingkat produksi dan volume penjualan bawang daun organik dan anorganik di Koperasi Mitra Sejahtera Cianjur, dapat disimpulkan sebagai berikut:

1. Diketahui bahwa tingkat produksi bawang daun organik sebesar $335 \mathrm{~kg}$ dan bawang daun anorganik $360 \mathrm{~kg}$ dengan luas lahan sama yaitu $7500 \mathrm{M}^{2}$. Bawang daun anorganik lebih tinggi tingkat produksinya dibandingkan dengan bawang daun organik karena bawang daun anorganik diberikan perlakuan dengan menggunakan bahan-bahan kimia seperti pupuk kimia dan pestisida kimia yang meyebabkan pertumbuhan cepat.

2. Diketahui bahwa volume penjualan bawang daun organik sebesar Rp. 2.847.500 dengan nilai jual Rp. $8.500 / \mathrm{kg}$ sedangkan bawang daun anorganik sebesar Rp. $\quad 2.700 .000$ dengan nilai jual Rp. $7.500 / \mathrm{kg}$. Bawang daun organik lebih tinggi nilai jualnya karena permintaanya tinggi sedangkan produksinya sedikit dibanding bawang daun anorganik. Pada penelitian ini bawang daun organik lebih tinggi volume penjualanya dibandingkan dengan bawang daun anorganik dengan selisih Rp. 147.500.

\section{DAFTAR PUSTAKA}

Badan Pusat Statistik (BPS). 2016. Produksi Hortikultura dan Sayuran Tabunan, Jawa Barat. Jawa Barat
Budianto. 2016. Asyiknya bertanam Sayuran Hias Organik di Halaman Rumah. Yogyakarta: Araska.

Cahyono. 2005. Teknik Budidaya dan Analisis Usaha Tani Bawang Daun. Kanisius. Yogyakarta.

Cahyono. 2009. Kajian Tentang Pengelolaan Sumber Daya Air Oleh Petani Ikan Keramba Jaring Apung Dalam Pemanfaatan Secara Ekonomis Di Kawasan Danau Nibung Kab. Mukomuko. S2 Teknik Sipil. Universitas Gadjah Mada. Yogyakarta.

Kotler, Amstong. 2006. Prinsip-Prinsip Pemasaran. Edisi Keduabelas. Jilid 1. Jakarta:Erlangga

Mukhtar. 2013. Metode Praktis Penelitian Deskriftif Kualitatif. Jakarta Selatan: Referensi (GP Press Group).

Nawawi. 2012. Metode Penelitian Bidang Sosial. Yogyakarta: Gajah Mada University Press.

Rudianto. 2015. Akuntansi Koperasi Edisi Kedua. Jakarta. Erlangga.

Rukmana. 2008. Bertanam dan Pengolahan Pascapanen. Yogyakarta: Kanisius.

Sadono, Sukirno. 2008. Mikroekonomi: Teori Pengantar. Jakarta: PT Raja Grafindo Persada

Sotopo. 2006. Metodologi Penelitian Kualitatif. Surakarta: UNS

Sudarman, Ari. 2004. Teori Ekonomi Mikro. Edisi 4. Yogyakarta.

Sugiarto. 2002. Psikologi Pelayanan Dalam Industri Jasa. PT Gramedia Pustaka Utama. Jakarta.

Sugiyono. 2007. Metode Penelitian Bisnis . Bandung : CV, Alfabeta.

Sutanto. 2002. Pertanian Organik. Kanisius. Yogyakarta.

Sutrisno. 2013. Manajemen Sumber Daya Manusia. Yogyakarta: Prenada Media. 